\title{
Comparison of phosphorus recovery from incineration and gasification sewage sludge
} ash

Parés Viader, Raimon; Jensen, Pernille Erland; Ottosen, Lisbeth M.; Thomsen, Tobias Pape; Ahrenfeldt, Jesper; Hauggaard-Nielsen, Henrik

Published in:

Water Science and Technology

Link to article, DOI:

10.2166/wst.2016.620

Publication date:

2017

Document Version

Peer reviewed version

Link back to DTU Orbit

Citation $(A P A)$ :

Parés Viader, R., Jensen, P. E., Ottosen, L. M., Thomsen, T. P., Ahrenfeldt, J., \& Hauggaard-Nielsen, H. (2017). Comparison of phosphorus recovery from incineration and gasification sewage sludge ash. Water Science and Technology, 75(5), 1251-1260. https://doi.org/10.2166/wst.2016.620

\section{General rights}

Copyright and moral rights for the publications made accessible in the public portal are retained by the authors and/or other copyright owners and it is a condition of accessing publications that users recognise and abide by the legal requirements associated with these rights.

- Users may download and print one copy of any publication from the public portal for the purpose of private study or research.

- You may not further distribute the material or use it for any profit-making activity or commercial gain

- You may freely distribute the URL identifying the publication in the public portal 


\title{
Comparison of phosphorus recovery from incineration and gasification sewage sludge ash
}

\author{
Raimon Parés Viader*, Pernille Erland Jensen*, Lisbeth M. Ottosen*, Tobias P. Thomsen**, Jesper \\ Ahrenfeldt**, Henrik Hauggaard-Nielsen*** \\ * Department of Civil Engineering, Technical University of Denmark, Building 118, 2800 Kongens Lyngby, \\ Denmark (E-mail: rapv@byg.dtu.dk) \\ ** Department of Chemical and Biochemical Engineering, Building 313, Technical University of Denmark, 4000 \\ Roskilde, Denmark \\ *** Department of Environmental, Social and Spatial Change, Roskilde University, 4000 Roskilde, Denmark
}

KEYWORDS: Electrodialysis, Heavy metals, Incineration, Low-temperature gasification, Phosphorus, Sewage sludge ash

\begin{abstract}
Incineration of sewage sludge is a common practice in many western countries. Gasification is an attractive option because of its high energy efficiency and flexibility in the usage of the produced gas. However, they both unavoidably produce sewage sludge ashes, a material which is rich in phosphorus, but that it is commonly landfilled or used in construction materials. With current uncertainty in phosphate rock supply, phosphorus recovery from sewage sludge ashes has become interesting. In the present work, ashes from incineration and gasification of the same sewage sludge were compared in terms of phosphorus extractability using electrodialytic methods. The results show that comparable recovery rates of phosphorus were achieved with a single electrodialytic step for incineration ashes and a sequential combination of two electrodialytic steps for gasification ashes, which was due to a higher influence of iron and/or aluminium in phosphorus solubility for the latter. A product with lower level of metallic impurities and comparable to wet process phosphoric acid was eventually obtained from gasification ashes. Thus, gasification becomes an interesting alternative to incineration also in terms of phosphorus separation.
\end{abstract}

\section{INTRODUCTION}

Increasing global food demand requires greater use of phosphorus (P) from phosphate rock (PR), a mineral which is unevenly distributed worldwide (USGS 2015) and whose geopolitical concerns increases the risk of supply disruption (Cordell \& White 2014). Since P is non-renewable on a human time scale (van Dijk et al. 2016), there is a need for recycling technologies. In this context, P recovery from secondary resources like sewage sludge ashes (SSAs) becomes an interesting alternative. Energy recovery processes, like incineration, have been adopted for some of the sewage sludge in developed economies like Europe, Japan or the United States (Samolada \& Zabaniotou 2014). However, only a minor part of the resulting SSA are used in the production of fertilizers, due to the presence of heavy metals (HMs) (Ottosen et al. 2013; Ebbers et al. 2015; Parés Viader et al., 2015) and the high content of $\mathrm{Al}$ and $\mathrm{Fe}$, which makes it unsuitable for traditional processing methods of PR (Scholz et al. 2014). Thus, around 300,000 Mg of mono-incineration SSA are produced per year in Germany, the biggest producer in the European Union (EU), most of which is currently landfilled or used in construction materials (Krüger et al. 2014, 2015). In this country, as well as in other major SSA producers like Netherlands and Switzerland, there have been recently 
several agreements in order to setup pilot plants in the coming years, so as to investigate the recovery of $\mathrm{P}$ from incineration SSA in an industrial usable form, like $\mathrm{H}_{3} \mathrm{PO}_{4}$ solutions.

Gasification of sewage sludge is an interesting alternative to incineration because of a high energy efficiency, less extensive gas cleaning to avoid air pollution and a more flexible use of the syngas produced, which can be employed in several processes like combined heat and power or chemicals production (Ahrenfeldt et al. 2013; Samolada \& Zabaniotou 2014). So far, gasification of sewage sludge has not been as extended as incineration, due to the complexity of the technology and its investment and operational costs (Samolada \& Zabaniotou 2014); for instance, there are only two fluidised bed gasification plants in Germany with a combined production of less than 6,000 tonnes of SSA per year (Krüger \& Adam 2015). Moreover, the direct application of gasification biochar/SSA as fertilizers can also be limited by the heavy metal (HM) content, as well as due to the low plant availability of P.

Previous researches focused on the characterisation of SSA from incineration (Franz 2008; Donatello et al. 2010; L. M. Ottosen et al. 2013) or gasification (Hernandez et al. 2011; Martinez et al. 2014; Parés Viader et al. 2015), including element composition and acid extraction of P and other elements. Electrodialytic (ED) methods have also been investigated to recover $\mathrm{P}$ from incineration and low-temperature (LT) gasification SSA with high content in $\mathrm{Fe}$ and $\mathrm{Al}$, and separate it from impurities like HMs (Parés Viader et al., 2016). ED setups comprise several compartments delimitated by ion exchange membranes; by applying an electrical current, the different elements are released from the bulk ash, and positively charged metallic species are separated from the $\mathrm{P}$ anions in the different compartments through electromigration. The setup used differed for each ash: up to $96 \%$ of $\mathrm{P}$ extraction was achieved for incineration SSA with a 2compartment (2C) ED setup (Ebbers et al. 2015), whereas the recovery was around 70\% for LT gasification SSA (Parés Viader et al., 2016) using a sequential ED process (Fig.1a). However, the sewage sludge originally used in each thermal treatment was different, and so was the composition of the resulting ashes; in the case of $\mathrm{P}$, its content was considerably higher for incineration (12.3\%) than for the LT gasification SSA (3.0\%). The present study compares the chemical composition, acid and alkaline leachability, as well as the ED P-recovery from SSA produced either by incineration or LT gasification of sewage sludge from the same wastewater treatment plant (WWTP).

\section{METHODS}

\section{Experimental SSA}

Two different SSA were produced for this research using the same feedstock: sewage sludge collected at the WWTP in the municipality of Bjergmarken, Denmark, where P was captured, approximately, 70\% biologically and 30\% chemically with Fe chloride sulphate. Al chloride was also used to flocculate and precipitate filamentous bacteria in the sedimentation tank, and its dosing varied during the days that the sewage sludge samples were collected.

Incineration SSA: collected from the mono-incineration plant in Avedøre Wastewater Service, Denmark in a fluidized bed combustor at around $840^{\circ} \mathrm{C}$ after the sewage sludge was mechanically dewatered.

Gasification SSA: collected from the bottom of the char reactor of a $100 \mathrm{~kW}$ experimental LT Circulating Fluid Bed gasifier at the Department of Chemical and Biochemical Engineering, 
Roskilde campus of the Technical University of Denmark after the sewage sludge was dried. It was the same gasification unit used in previous researches (Hansen et al. 2015; Parés Viader et al. 2015, 2016).

\section{Analytical methods and sampling}

One batch of around 300 grams was sampled from the total mass collected, dried at $105^{\circ} \mathrm{C}$ overnight, cooled in the fume hood, homogenised with a steel spatula and immediately stored in plastic bags and under dry conditions. Gasification SSAs were loosed with a mortar to facilitate ED experiments.

The concentration of elements was investigated for the in fifteen samples for each untreated ash, and in triplicates after each ED experiments. The targeted elements were: $\mathrm{Al}, \mathrm{As}, \mathrm{Ca}, \mathrm{Cd}, \mathrm{Cu}, \mathrm{Cr}$, $\mathrm{Fe}, \mathrm{Mg}, \mathrm{Ni}, \mathrm{P}, \mathrm{Pb}, \mathrm{S}$ and $\mathrm{Zn}$. Their content was measured by Varian 720-ES inductively coupled plasma optical emission spectrometry (ICP-OES) after pre-treatment by Danish Standard 259:2003 (DS259): $1 \mathrm{~g}$ ash and 20mL $7.3 \mathrm{M} \mathrm{HNO}_{3}$ were heated at $200 \mathrm{kPa}\left(120^{\circ} \mathrm{C}\right)$ for $30 \mathrm{~min}$. The liquid was thereafter separated by vacuum filtration through a $0.45 \mu \mathrm{m}$ filter and diluted to $100 \mathrm{~mL}$ with deionised (DI) water.

The mineralogy of both SSA was examined using X-ray powder diffraction (XRPD) with a PANalytical X'Pert PRO, and the results were analysed using X'Pert HighScore Plus with ICDD PDF 2 database.

\section{pH release}

In order to assess the solubility of the target elements under acid or alkaline solutions, $2.5 \mathrm{~g}$ of ash was shaken at $150 \mathrm{rpm}$ for 1 week with $25 \mathrm{~mL}$ of $\mathrm{HNO}_{3}$ or $\mathrm{NaOH}$ in duplicates at $1,0.7,0.5,0.3$ and $0.1 \mathrm{M}$ respectively. The same procedure was repeated for de-ionised (DI) water. The $\mathrm{pH}$ of each leachate was measured by a PHM220 Lab pH Meter. Content of the targeted elements in the leachate was measured by the Varian 720-ES ICP-OES after filtration through a $0.45 \mu \mathrm{m}$ syringe filter, and compared to the total amount in the untreated ashes as described in the previous section.

\section{ED experimental setup}

An illustration of two of the ED methods used is shown in Fig. 1. The sequential process (Fig. 1a) was similar to a previous research (Parés Viader et al., 2016). The first step cell consisted of two compartments made of cylindrical Plexiglas ${ }^{\circledR}$ with an internal diameter of $8 \mathrm{~cm}$ separated by a cation exchange membrane (CEM). The anode compartment was $10 \mathrm{~cm}$ long and contained $35 \mathrm{~g}$ ash and $350 \mathrm{ml}$ DI water. The second step cell consisted also of two compartments of identical characteristics to the first step separated by an anion exchange membrane (AEM); in this case, the cathode compartment contained 20-25 g of the bulk ash resulting from the first step and $300 \mathrm{ml}$ of $\mathrm{NaOH} 0.15$ M. A plastic strip attached to a glass-stick connected to an overhead stirrer (IKA RW11) was used to stir the ash suspensions during the experiments. In the cathode compartment of the first step, $500 \mathrm{~mL}$ electrolyte solution $\left(0.01 \mathrm{M} \mathrm{NaNO}_{3}, \mathrm{pH}<2\right.$ adjusted with $\left.\mathrm{HNO}_{3}\right)$ was circulated by a Plastomec pump model P05. In the anode compartment of the second step, the anolyte resulting from the first step was circulated using the same pump model after vacuum filtration through a $0.45 \mu \mathrm{m}$ filter.

The split setup (Fig. 1b) consisted of three compartments made of Plexiglas ${ }^{\circledR}$ with an internal diameter of $8 \mathrm{~cm}$, in which the middle compartment was $10 \mathrm{~cm}$ long and contained $35 \mathrm{~g}$ ash and $350 \mathrm{ml}$ DI water. One electrode was placed in each compartment, and the cathode was simultaneously connected to two anodes by means of two power supplies. An AEM was placed between the two anode compartments, whereas a CEM was placed between the middle and the 
cathode compartment. In the end anode compartment, $500 \mathrm{~mL}$ of $0.01 \mathrm{M} \mathrm{H}_{3} \mathrm{PO}_{4}$ was circulated, whereas in the cathode compartment $500 \mathrm{~mL}$ of electrolyte solution $\left(0.01 \mathrm{M} \mathrm{NaNO}_{3}, \mathrm{pH}<2\right.$ adjusted with $\mathrm{HNO}_{3}$ ) was circulated; in both cases using the same model pump as before. With this setup, it was expected to achieve:

a) A similar degree of cationic migration as in a $2 \mathrm{C}$ setup, as the electrical current at the cathode was the same (50 mA, see next section).

b) Less solubilisation of metals with lower acid-leachability than $\mathrm{Ca}$ (like $\mathrm{Fe}$ or $\mathrm{Al}$ ), since the ash suspension was subjected to half the current (25 mA) than in the $2 \mathrm{C}$ setup, and thus a lower proton load generate at the anode by electrolysis.

In order to accelerate the $\mathrm{pH}$ decrease at the beginning of the split ED experiments, $50 \mathrm{~mA}$ were applied only between the anode in the middle compartment and the cathode for the first 6 (Incineration SSA) and 48 hours (Gasification SSA).

The electrodes were made of platinum coated titanium wire (diameter $3 \mathrm{~mm}$ ) obtained from Permascand ${ }^{\circledR}$. An Agilent E3612A DC power supply was used to maintain a constant DC current. The CEM and AEM used were from Ionics (model CR67 and AR204SZRA respectively).

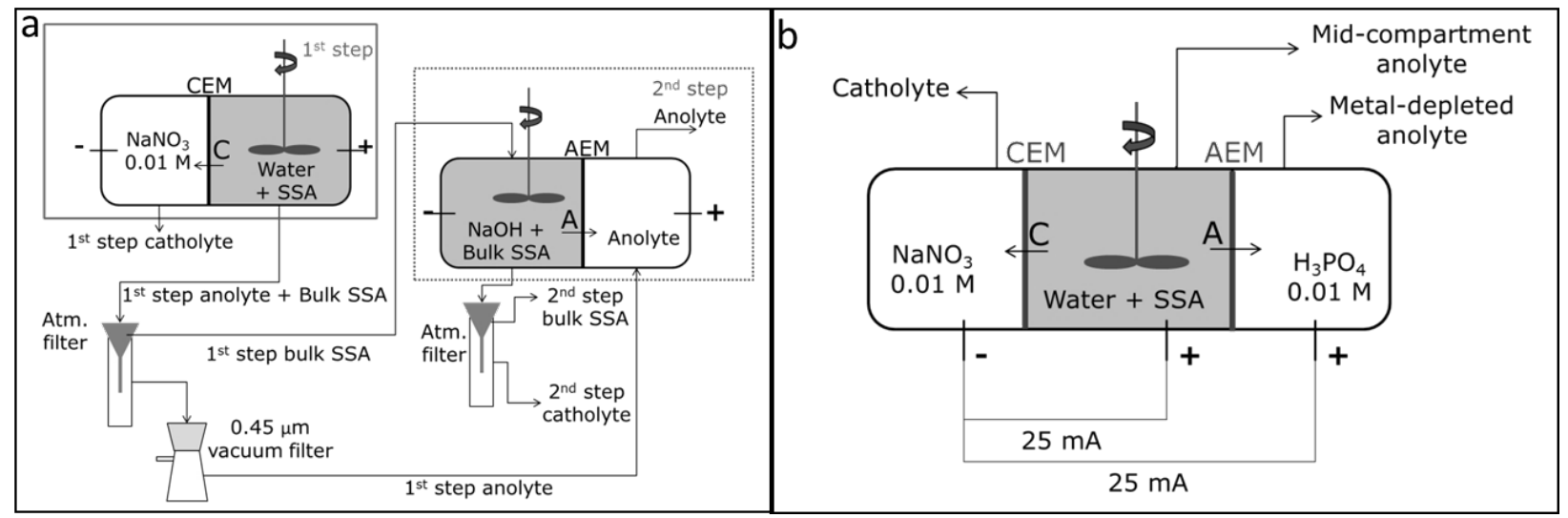

Fig. 1. Schematic view of the sequential ED process (a) and the split ED setup (b). C: cations, A: anions.

\section{ED experiments}

Eleven sets of ED experiments were made (Table 1): five for Incineration (I1-I5) and six for Gasification SSA (G1-G6). For the former, all experiments consisted of a single step, whereas a sequential process was used in four experiments for the latter. The intensity was $50 \mathrm{~mA}$, chosen following the findings from previous researches using ED on incinerated and gasified SSA (Parés Viader et al., 2016). Voltage between the electrodes was monitored during the whole experiment. The $\mathrm{pH}$ in both compartments and the conductivity of the ash suspension were measured twice a day during the ED experiments. The $\mathrm{pH}$ of the catholyte of the first step was adjusted to $<2$ with $\mathrm{HNO}_{3} 5 \mathrm{M}$, to avoid precipitations due to the production of $\mathrm{OH}-$ by the electrode reaction at the inert cathode. 
Table 1. Names and conditions of the ED experiments.

\begin{tabular}{|c|c|c|c|}
\hline $\begin{array}{c}\text { Experiment } \\
\text { name }\end{array}$ & SSA used & $\begin{array}{l}\text { Experimental time } \\
\left(1^{\text {st }} / 2^{\text {nd }} \text { step }\right) \text { [Days] }\end{array}$ & ED setup \\
\hline I1 & \multirow{5}{*}{ Incineration } & 5 & \multirow{2}{*}{$2 \mathrm{C}$} \\
\hline $\mathrm{I} 2$ & & 6 & \\
\hline I3 & & 6 & Split \\
\hline I4 & & 7 & \multirow{2}{*}{$2 \mathrm{C}$} \\
\hline I5 & & 8 & \\
\hline G1 & \multirow{6}{*}{ Gasification } & $4 / 5$ & \multirow{3}{*}{ Sequential 2C (both steps) } \\
\hline G2 & & $5 / 5$ & \\
\hline G3 & & $6 / 5$ & \\
\hline G4 & & $6 / 5$ & Sequential split (1 $1^{\text {st }}$ step) and 2C ( $2^{\text {nd }}$ step) \\
\hline G5 & & 7 & \multirow[t]{2}{*}{. } \\
\hline G6 & & 9 & \\
\hline
\end{tabular}

At the end of each step, the ash suspension was filtered at atmospheric pressure, and for the first step it was flushed with $200 \mathrm{~mL}$ of DI water in order to displace the elements in solution retained in the humidified ash. The resulting liquid volume was measured, and the ash was dried during 48 hours at $50{ }^{\circ} \mathrm{C}$. The dried ash was loosened by hand in a mortar and stored in plastic bags and under dry conditions. The electrodes were rinsed in $5 \mathrm{M} \mathrm{HNO}_{3}$, the membranes in $1 \mathrm{M} \mathrm{HNO}_{3}$. Catholyte and anolyte samples were taken in $20 \mathrm{~mL}$ vials before applying the electrical current and after 5 minutes of electrolyte circulation; at the end of all experiments, the catholyte and anolyte volumes were measured, and samples for each were also taken in $20 \mathrm{~mL}$ vials. The concentrations of the elements were measured in all of the liquids by ICP-OES after filtration through a $0.45 \mu \mathrm{m}$ syringe filter.

\section{Experimental ED parameters}

The ED experiments were evaluated in terms of rates of $\mathrm{P}$ recovery and the impurity level of the obtained product. The amounts of $\mathrm{P}$ found in the anolytes of the $1^{\text {st }}$ and $2^{\text {nd }}$ steps were considered as recovered, since they were expected to be solutions rich in this element and depleted of impurities like metallic cations. The overall \% of $\mathrm{P}$ recovered was calculated as:

$$
\% P \text { recovery }=\frac{P \text { in anolytes }}{\text { Total } P \text { at the end of the experiment }}
$$

And the amount of $\mathrm{P}$ in the anolytes was calculated as:

$$
V_{1^{s t} \text { step }} \cdot C_{P-1^{\text {st }} \text { step }}+V_{2^{n d} \text { step }} \cdot C_{P-2^{n d} \text { step }} \cdot \frac{m_{\text {ash }-1^{\text {st }} \text { step }}}{m_{a s h-2^{n d}} \text { step }}
$$

Where $\mathrm{V}_{1 \text { st step }}$ and $\mathrm{V}_{2 \text { nd }}$ step were the volumes of the anolytes, CP-1st step and Cp-2nd step the concentration of $\mathrm{P}$ in the anolytes at the end of each ED step, whereas mash-1st step were the mass of dry ash after the $1^{\text {st }}$ step and mash-2nd step the mass used in the $2^{\text {nd }}$ step. The inclusion of the ratio between $m_{\text {ash-1st step }}$ and $m_{\text {ash-2nd }}$ multiplying the second term was used to extrapolate the result of the $2^{\text {nd }}$ ED step to all the bulk dry ash mass after the $1^{\text {st }}$ step.

In order to assess the amount of impurities in the recovered $\mathrm{P}$, it was compared to WPA, the product of leaching PR with sulfuric acid (Gilmour 2014) which is applied to over 70\% of mined PR 
(Scholz et al. 2014). A common parameter to evaluate the level of impurities of WPA, and its suitability in the fertilizer industry is the minor element ratios (MER), defined as:

$$
M E R=\frac{\mathrm{Fe}_{2} O_{3}+\mathrm{Al}_{2} O_{3}+\mathrm{MgO}}{\mathrm{P}_{2} O_{5}}
$$

\section{RESULTS AND DISCUSSIONS}

\section{SSA characterisation}

Element concentrations of the two untreated ashes are shown in Table 2. Most elements presented a high standard deviation, as it can be expected in inherent inhomogeneous materials. Cd concentrations in the liquids from the DS259 pre-treatment of Gasification ash were found to be below the limit of detection (LOD, $0.02 \mathrm{ppm}$ ) in 12 out of 15 samples, and therefore the concentration is given as a range, and no mass balance or $\mathrm{pH}$ release result is shown for this element.

Table 2. Concentration (average \pm standard deviation) of elements in the two studied SSA. The results are compared with the element concentrations found in literature for incineration SSA and gasification SSA.

\begin{tabular}{cccccc}
\hline Element & $\begin{array}{c}\text { Incineration } \\
\text { SSA }\end{array}$ & $\begin{array}{c}\text { Gasification } \\
\text { SSA }\end{array}$ & $\begin{array}{c}\text { German } \\
\text { incineration SSA, } \\
\text { average values } \\
\text { (Krüger et al. } \\
\text { 2014) }\end{array}$ & $\begin{array}{c}\text { Gasification SSA } \\
\text { values in literature } \\
\text { (Gil-Lalaguna et al. } \\
2015 \text {; Hernandez et al. }\end{array}$ & Units \\
\hline Al & $28.3 \pm 4.4$ & $51.2 \pm 1.1$ & 52 & 2011 ) & \\
Ca & $132 \pm 47$ & $135 \pm 27$ & 138 & $23-61$ & $\mathrm{~g} / \mathrm{kg}$ \\
$\mathbf{F e}$ & $63.2 \pm 13$ & $61 \pm 1.8$ & 99 & $84-148$ & $\mathrm{~g} / \mathrm{kg}$ \\
$\mathbf{M g}$ & $11.9 \pm 2.2$ & $12.9 \pm 1.3$ & 14 & $88-123$ & $\mathrm{~g} / \mathrm{kg}$ \\
$\mathbf{P}$ & $88.4 \pm 21$ & $96.0 \pm 15$ & 90 & $25-36$ & $\mathrm{~g} / \mathrm{kg}$ \\
$\mathbf{S}$ & $8.77 \pm 2.1$ & $5.58 \pm 0.5$ & 15 & $51-149$ & $\mathrm{~g} / \mathrm{kg}$ \\
$\mathbf{A s}$ & $11.4 \pm 1.4$ & $5.82 \pm 0.33$ & 17.5 & $0.2-41$ & $\mathrm{~g} / \mathrm{kg}$ \\
$\mathbf{C d}$ & $4.19 \pm 2.8$ & $<2-3.6$ & 3.3 & $\mathrm{~N} / \mathrm{A}$ & $\mathrm{mg} / \mathrm{kg}$ \\
$\mathbf{C r}$ & $57.7 \pm 4.3$ & $89.2 \pm 7.4$ & 267 & $2 \mathrm{LOD}$ & $\mathrm{mg} / \mathrm{kg}$ \\
$\mathbf{C u}$ & $588 \pm 43$ & $479 \pm 31$ & 916 & $1,159-1,367$ & $\mathrm{mg} / \mathrm{kg}$ \\
$\mathbf{N i}$ & $58.1 \pm 3.7$ & $57.9 \pm 9.7$ & 105.8 & $122-165$ & $\mathrm{mg} / \mathrm{kg}$ \\
$\mathbf{P b}$ & $208 \pm 100$ & $137 \pm 87$ & 151 & $51-90$ & $\mathrm{mg} / \mathrm{kg}$ \\
$\mathbf{Z n}$ & $2,120 \pm 230$ & $1,650 \pm 250$ & 2,535 & $753-877$ & $\mathrm{mg} / \mathrm{kg}$ \\
& & & & & $\mathrm{mg} / \mathrm{kg}$ \\
\hline
\end{tabular}

Average concentrations of $\mathrm{Ca}, \mathrm{P}, \mathrm{Fe}$ and $\mathrm{Mg}$ for Incineration compared to Gasification ashes were in the range of $\pm 10 \%$, and therefore a fair comparison of both SSA in terms of P leachability and ED-recovery can be made. Differences in $\mathrm{Al}$ are probably attributable to differences in the dosing of aluminium chloride in the WWTP (see section Experimental SSA). S and HMs content were on average slightly higher for Incineration SSA, which is probably because they were produced by mixing of fly ashes and bottom ashes. In contrast, gasification SSA consists only of the bottom ash fraction; the higher concentration for $\mathrm{Cr}$ is most likely due to releases from the materials used in the gasifier, although it requires further study. 
Incineration SSA concentrations were compared to the average values from a survey of incineration SSA in Germany (Krüger et al. 2014). P concentrations were found to be very similar, considering only values from municipal SSA. Differences in $\mathrm{Al}$ and $\mathrm{Fe}$ can be due to a higher dosing of $\mathrm{Al}$ and Fe salts in German WWTP. As, $\mathrm{Cr}, \mathrm{Cu}, \mathrm{Ni}$ and $\mathrm{Zn}$ concentrations were on average higher in German SSA, which is because the survey included a mean value including both municipal and industrial SSA. Concentrations in the Gasification ashes of this study were compared to previous researches on gasification SSA (Hernandez et al. 2011; Gil-Lalaguna et al. 2015). On average, Al, $\mathrm{Ca}, \mathrm{P}, \mathrm{S}$ and $\mathrm{Cr}$ content were in the range of literature values, whereas the rest of elements were below it, except for $\mathrm{Pb}$ and $\mathrm{Zn}$. The reason for the lower Fe concentration can be again a lower dosing of Fe salts in Bjergmarken WWTP.

The mineralogy study showed two common phases for both SSA: quartz $\left(\mathrm{SiO}_{2}\right)$ and calcium phosphates $\left(\mathrm{Ca}_{9} \mathrm{Fe}\left(\mathrm{PO}_{4}\right)_{7}, \mathrm{Ca} 9 \mathrm{Al}\left(\mathrm{PO}_{4}\right)_{7}\right.$ and/or $\left.\mathrm{Ca} 7 \mathrm{Mg}\left(\mathrm{PO}_{4}\right)_{6}\right)$. For Incineration SSA, hematite $\left(\mathrm{Fe}_{2} \mathrm{O}_{3}\right)$ and anhydrite $\left(\mathrm{CaSO}_{4}\right)$ were also identified. These phases were respectively identified in other incineration (Franz, 2008; Donatello et al. 2010; Ottosen et al. 2014; Li et al. 2015) and gasification SSA (Hernandez et al. 2011; Gil-Lalaguna et al. 2015).The presence of $\mathrm{Fe}_{2} \mathrm{O}_{3}$ in incineration SSA is due to the reaction of iron phosphate with lime, and the consequent formation of more acid-soluble calcium phosphate (Martinez et al. 2014; Li et al. 2015). In contrast, the lack of hematite in Gasification SSA could indicate the presence of $\mathrm{FePO}_{4}$, although it was not identified neither in the XRPD analyses of the present work nor in previous studies on gasification SSA (Hernandez et al. 2011; Gil-Lalaguna et al. 2015). One reason could be that it was found in an amorphous phase, since there was a hump in the pattern from $10^{\circ}$ to $40^{\circ}(2 \theta)$, but it requires further study.

\section{pH release experiments}

The solubilisation of all elements generally increased with lower $\mathrm{pH}$ values for both Incineration and Gasification SSA (Fig. 2). P leaching was lower for Gasification than for Incineration SSA on each acid concentration, except for the highest acid load (1 $\left.\mathrm{M} \mathrm{HNO}_{3}\right)$. In fact, $\mathrm{P}$ was not completely solubilised in this acidic extraction (88\% with $\mathrm{pH} 0.7$ ) for Incineration ashes; this is in contradiction with the results obtained in previous studies (Ottosen et al. 2013), where most P was extracted at $\mathrm{pH} 1$, and it is most likely due to the inherent inhomogeneity of the ashes. $\mathrm{P}$ concentrations were $8.1 \cdot 10^{-2} \mathrm{M}$ at $\mathrm{pH} 2.4$ for Incineration, and $3.4 \cdot 10^{-2} \mathrm{M}$ at $\mathrm{pH} 1.9$ for Gasification ashes; Fe(III), Aland Ca- phosphates solubility at $\mathrm{pH} 2$ are in the range of $10^{-3}-10^{-4} \mathrm{M}, 10^{-3}-10^{-2}$ and $>1 \mathrm{M}$, respectively (Stumm \& Morgan 1996; Kuroda \& Okido 2012). Thus, P release is influenced simultaneously by these three metals for both SSA at low $\mathrm{pH}$, with a higher influence of $\mathrm{Al}$ and $\mathrm{Fe}$ in Gasification than in Incineration ashes. At high $\mathrm{pH}$ values, $\mathrm{P}$ solubilised for both SSA, but to a higher degree for Gasification. This suggests the presence of alkaline-soluble $\mathrm{P}$ bindings, like Fe(III)-P and/or Al-P, as previously seen for other LT gasification SSA (Parés Viader et al., 2016). Nevertheless, P-solubility for Gasification SSA at pH $1.9\left(3.4 \cdot 10^{-2} \mathrm{M}\right)$ was one order of magnitude higher than in these LT gasification ashes at $\mathrm{pH} 2.1\left(2.6 \cdot 10^{-3} \mathrm{M}\right)$ (Parés Viader et al. 2015), probably because a higher proportion of chemically captured $\mathrm{P}(50 \%)$ in the original sewage sludge of the latter. For Incineration SSA, Fe leaching was lower than in Gasification ashes in all acidic $\mathrm{pH}$ values, which can be due to the formation of acid-insoluble iron oxides from Fe-phosphates in the former (see section SSA characterisation). 


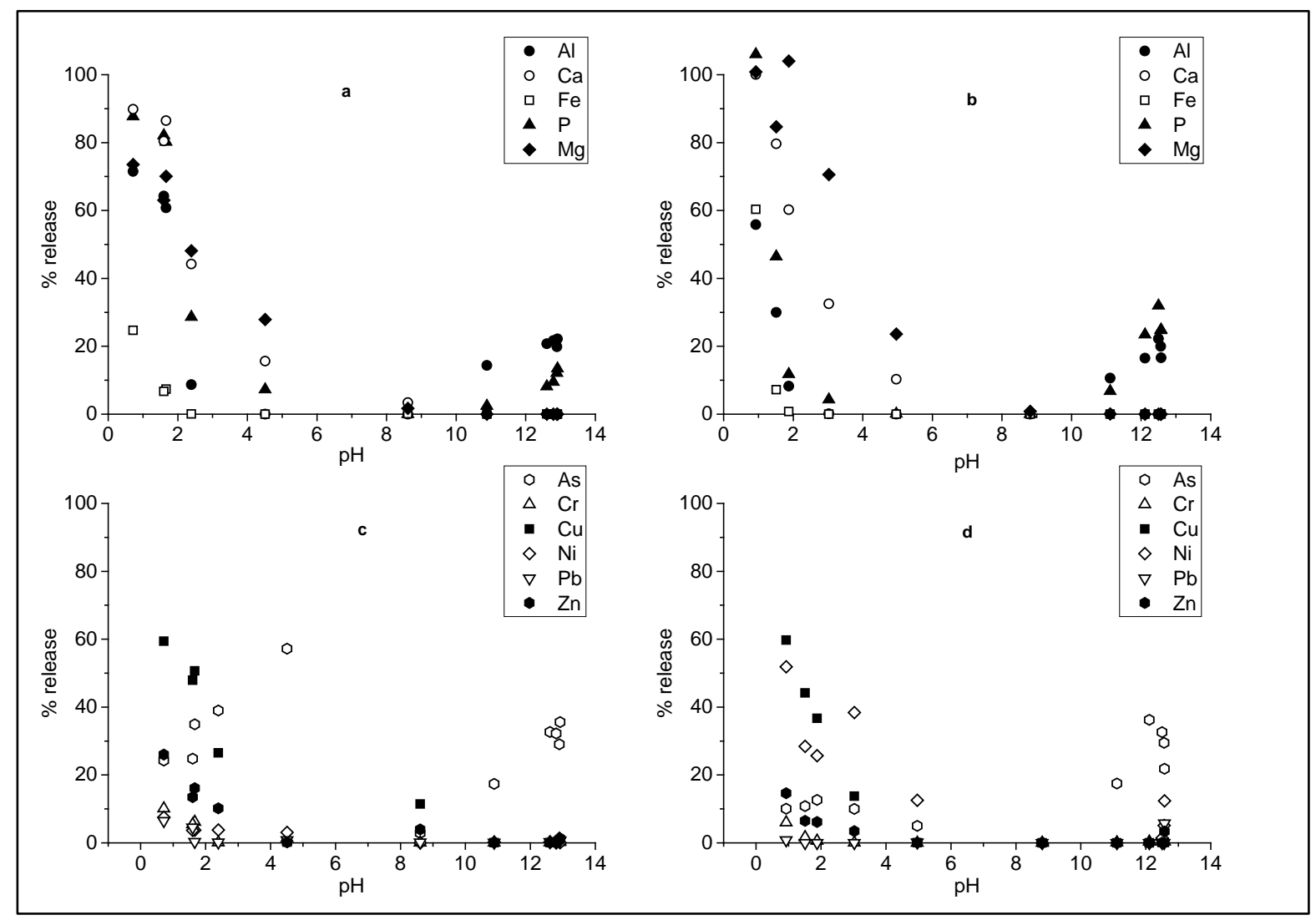

Fig. 2. pH release of the studied elements in Incineration (a,c) and Gasification (b,d) SSA.

The concentrations of most HMs in the acidic leachates of Incineration ashes were higher than the values of Gasification ashes leachates, with $\mathrm{As}, \mathrm{Pb}$ and $\mathrm{Zn}$ being at least a twofold higher, for the same $\mathrm{HNO}_{3}$ load. On the contrary, Ni leachability in all acid tests was around one order of magnitude higher in Gasification SSA; the results for Incineration SSA at pH 0.7 (7.5\%) were also lower than the results from a previous work with similar incineration SSA at around $\mathrm{pH} 1(\sim 35 \%)$ (Ottosen, et al. 2013). Leachate concentrations under alkaline extractions were higher for As in Incineration and for $\mathrm{Ni}$ in Gasification SSA, while the rest of $\mathrm{HMs}$, together with $\mathrm{Fe}$ and $\mathrm{Al}$, leached below $5 \%$ for both SSA, probably because of the formation of metallic hydroxides.

\section{ED experiments}

\section{Mass balances}

The element distribution in the different compartments at the end of the experiments was determined, considering that:

- The catholyte, the cathode and the cationic membrane were grouped as the cathode compartment in the $1^{\text {st }}$ step. In the $2^{\text {nd }}$ step, the cathode compartment comprised the cathode and the catholyte.

- The total mobilisation or release of each element, including $\mathrm{P}$, was the sum of the masses found in all electrolyte solutions, membranes and electrodes at the end of the experiments minus the initial concentrations of these elements in these compartments. 
- In the split experiment $\mathrm{I} 3$, the $\mathrm{P}$ in both anolyte liquids (mid-compartment and metaldepleted) was considered as recovered. For split experiment G4, only the P in the metaldepleted anolyte was considered as recovered since its amounts was over 50 times higher than the one found in the mid-compartment anolyte. Furthermore, the ratio of metals to $\mathrm{P}$ in the anolytes of the split experiments was calculated by the difference between the concentrations at the end and at the beginning of the experiments.

- The amount of each element migrated to the catholyte in the $1^{\text {st }}$ step, and to the anolyte in the $2^{\text {nd }}$ step was defined as the difference in each element amount in the electrolyte solution at the end minus at the start of the step.

Mass balances for each element (except Cd), defined as the division of the amount found at the end of the experiments by the mass initially found in the initial SSA and the liquids placed in the ED cell, were made to control the quality of each step of the experiments. Most elements in each step were found in the range or around $80-120 \%$, except for $\mathrm{Pb}(52-144 \%$ ), which is due to its inhomogeneity in both SSA (Table 2). Concentration measurements which were below the LOD used in the ICP-OES analyses $(0.02 \mathrm{mg} / \mathrm{L})$, were considered to have this value, except for the initial $1^{\text {st }}$ step catholyte samples, which were considered to be zero. This enabled to calculate the mass balances and the worst-case value for the ratio HM/P in the anolytes, which was the recovered Pproduct. The overall impact of these approximations was below $1 \%$ of the total final element mass found at the end of the ED experiments.

ED cell voltage, ash suspension conductivity and $p H$

The voltage between electrodes decreased during the $1^{\text {st }}$ step of most ED experiments, in parallel to the increase in electrical conductivity. At the same time, the $\mathrm{pH}$ decreased in the SSA suspensions to $2 \pm 0.3$ for all experiments except for I5 (1.3) and G4 (2.4). The main reason for this was the generation of protons in the anode together with the element release from the ashes. The sole exception was experiment G4, as the voltage in both power supplies increased from 8 to $17 \mathrm{~V}$ between 48-96 hours, and decreased afterwards to $10 \mathrm{~V}$. This increase suggests the migration of ions other than protons from the suspension, which entailed a decrease in conductivity, since its $\mathrm{pH}$ was stable in the range 2.4-2.8 after 48 hours. In the $2^{\text {nd }}$ step of G1-G4, the voltage increased after approximately 24 hours from $\sim 7 \mathrm{~V}$ to $\sim 25 \mathrm{~V}$ and decreased progressively the following 24 hours to $\sim 7 \mathrm{~V}$. This can be caused by a temporary fouling of the membrane, which was not observed in previous experiences (Parés Viader et al. 2015, 2016), and needs to be addressed in future research. In all experiments, the $\mathrm{pH}$ increased steadily up to 12 after 48 hours, and reached $\sim 12.5$ at the end of the experiments.

\section{P-recovery in ED experiments}

Fig. 3 shows that a higher extraction of $\mathrm{P}$ to the anolytes was achieved with longer experimental times using the 2C setup (not considering the split setup) for Incineration SSA, with the exception of the 5-day experiment. Moreover, there was a sharp increase between the 7- and the 8-day tests. Since Ca represented more than $80 \%$ of the mobilised metal mass in all experiments, the reason can be a higher amount of $\mathrm{P}$ (Fig. 3) and a higher proportion of Ca-P bindings over other Cacompounds for the ashes in experiments I1 and I5: the molar ratio of mobilised Ca to P (mobilised $\mathrm{Ca} / \mathrm{P}$ ) was around 1.4 , close to the one of tricalcium phosphate (1.5), and lower than for I2 (2.2) and I4 (2.0). Thus, there was a lower content of compounds competing with Ca-P dissolution, like $\mathrm{CaSO}_{4}$ or $\mathrm{CaCO}_{3}$, in $\mathrm{I} 1$ and I5. For Gasification SSA, higher P-extractions were also generally achieved at longer remediation times in the $1^{\text {st }}$ step (not considering the split setup, Fig. 3). 
Nevertheless, the amount of P extracted was lower for Gasification ashes after 5, 6, and 7 days in the $1^{\text {st }}$ step than after the treatment of Incineration ashes with the same times (Fig. 3). The reason can be the higher influence of $\mathrm{Fe}(\mathrm{III})$ and $\mathrm{Al}$ in $\mathrm{P}$ solubility in the Gasification SSA (see section $\mathrm{pH}$ release experiments). In fact, most $\mathrm{P}$ in the bulk SSA after the $1^{\text {st }}$ step would be bound to $\mathrm{Fe}(\mathrm{III})$ and/or $\mathrm{Al}$, as molar $\mathrm{Ca} / \mathrm{P}$ ranged from 0.3 (G5 and G6) to 0.6 (G1), well below the value of tricalcium phosphate (1.5). Higher remediation time in the ED experiment increased the amount of P migrated to the cathode compartment (Fig. 3) and a higher MER in the anolyte (Table 3). This was probably due to a higher solubilisation of Fe (III), which enabled the formation of positively charged complexes with phosphate ions, preventing their effective separation (Parés Viader et al. 2015). Therefore, in order to increase P recovery, a sequential ED process needs to be used (Fig. 3a), so that $\mathrm{Fe}(\mathrm{III})-\mathrm{P}$ bindings are solubilised through an increase of $\mathrm{pH}$, and $\mathrm{Fe}(\mathrm{III})$ is precipitated as hydroxides. A second step was applied to the ashes of the three shortest remediation times (G1G3), increasing the extraction to the levels achieved with Incineration ashes (Fig. 3). For G1, the amount of $\mathrm{P}$ recovered was higher than for G5 with the same total duration of the ED treatment (9 days). The molar $\mathrm{Ca} / \mathrm{P}$ in the bulk Gasification SSA after the $2^{\text {nd }}$ step was around 1.2 for the three experiments, which could be translated into an $80 \%$ of $\mathrm{P}$ bound to $\mathrm{Ca}$. In consequence, most existing Fe(III)-P and Al-P bindings were effectively dissolved. The achieved P-recoveries were up to $80 \%$ (I5) from Incineration ash and up to 69\% (G2) for Gasification ashes, which are similar to previous ED recoveries achieved on incineration and LT gasification SSA (Ebbers et al. 2015; Parés Viader et al., 2016). All recoveries can be seen in Table 3.

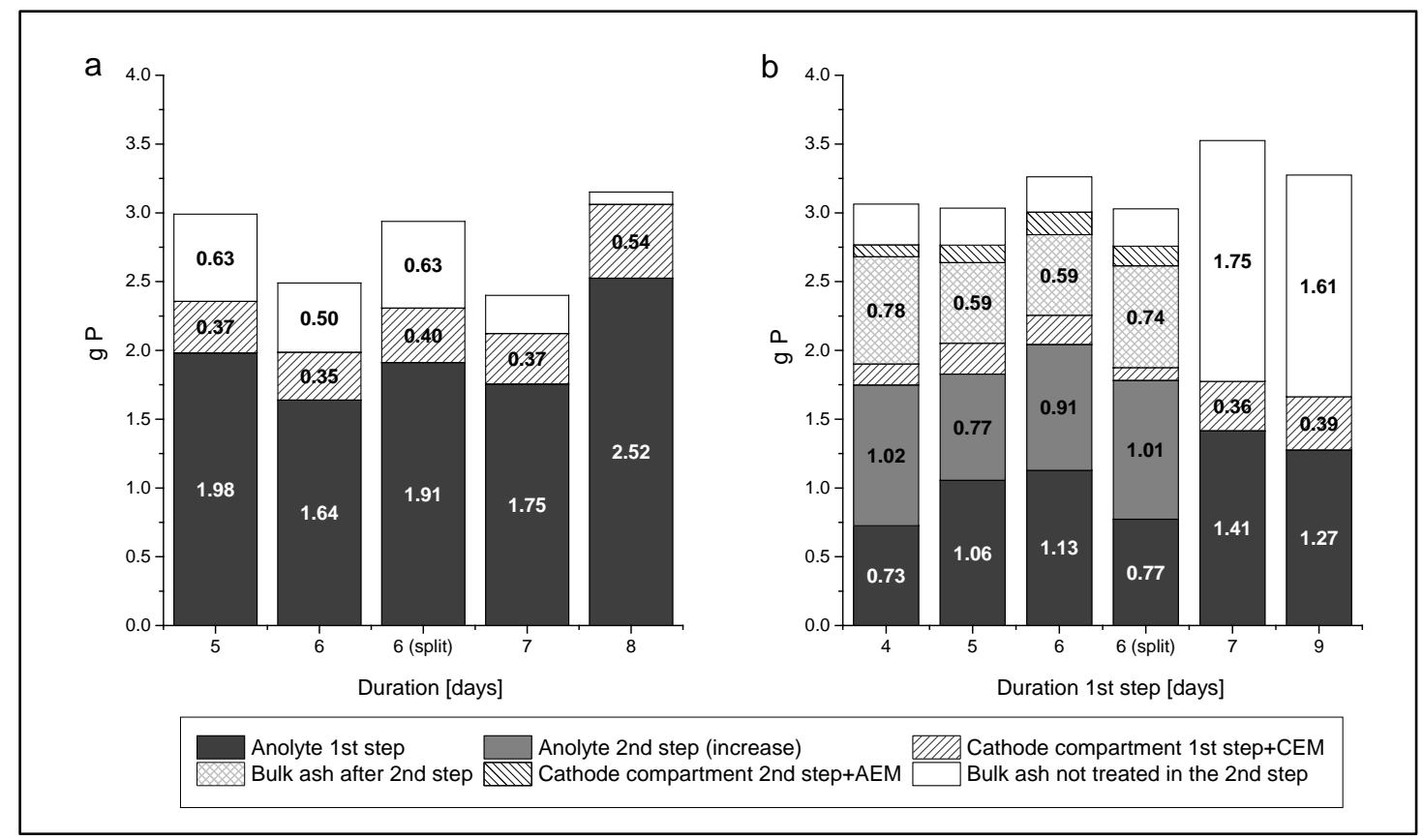

Fig. 3. P distribution at the end of the ED experiments for Incineration (a) and Gasification (b) SSA.

\section{Characteristics of the recovered $P$-liquids}

The resulting anolytes were acidic $(\mathrm{pH}<2)$, and the achieved $\mathrm{P}$-concentrations were higher than in previous researches, where the concentration was below $2 \mathrm{~g} P$ per litre (Parés Viader et al., 2016), but several orders of magnitude below the concentration found in WPA (Table 3), which needs to be addressed together with the high proportion of $S$ in the solution. 
The ratios of $\mathrm{Al}, \mathrm{Fe}$ and $\mathrm{Mg}$ to $\mathrm{P}$ in the resulting P-liquids were generally higher for Incineration than for Gasification ashes (G1-G4, Table 3). This is due to the lower solubility of Al in Gasification than Incineration SSA at $\mathrm{pH} 2$ (Fig. 2) and the use of the $2^{\text {nd }}$ step, since $\mathrm{Fe}$ and $\mathrm{Mg}$ were not soluble at $\mathrm{pH} 12$ (see Fig. 2 and section $\mathrm{pH}$ release experiments). An adaptation of the sequential ED process to treat Incineration SSA could therefore be beneficial, but it requires further study. However, MER values achieved using 2C setups were always above 0.085 , the technical limit of WPA to be used in Diammonium Phosphate (DAP), the world's more common mineral fertilizer (Gilmour 2014). This was also observed in previous ED treatment of incineration SSA (Ebbers et al. 2015). In order to reduce this ratio, the split setup (Fig. 1b) was used for both ashes (I3 and G4); for Gasification, as a $1^{\text {st }}$ step. The amount of P extracted with this setup was in line with the other results (Fig. 3), and at the same time a lower MER (and below 0.085, Table 3) was achieved.

$\mathrm{HM} / \mathrm{P}$ ratios in the anolytes were below the initial SSA ones (calculated from the average values in Table 2) and, for some elements, in the range or below the values found in WPA. Remarkably, some P-liquids from Gasification ash had only $\mathrm{Pb} / \mathrm{P}$ values above these ranges. Overall, the ratio of $\mathrm{As}, \mathrm{Cr}, \mathrm{Cu}, \mathrm{Ni}, \mathrm{Pb}$ and $\mathrm{Zn}$ to $\mathrm{P}$ were higher in Incineration than in Gasification ashes. This is probably due to the lower solubility of some of these metals in acid medium in the latter, as well as the use of the $2^{\text {nd }}$ ED step (experiments G1-G4), where most HMs became insoluble due to the alkaline conditions (see section $\mathrm{pH}$ release experiments). Additionally, the higher concentration of $\mathrm{S}$ in the anolyte solutions of Incineration SSA (Table 3) could enable the formation of neutrally charged sulphate complexes with $\mathrm{Cu}, \mathrm{Ni}, \mathrm{Pb}$ and $\mathrm{Zn}$, like $\mathrm{NiSO}_{4}(\mathrm{aq})$, although it requires further study. The use of a split setup allowed generally lower of $\mathrm{Cr}, \mathrm{Cu}$ and $\mathrm{Zn}$ to $\mathrm{P}$; especially for Gasification ash, because the final $\mathrm{pH}$ in the ash compartment (2.4) was higher than the other $1^{\text {st }}$ step experiments with the $2 \mathrm{C}$ setup $(\sim 2)$. 
Table 3. P-recovery (\%) and parameters of the anolyte solutions at the end of each experiment. The results are compared with the values found in WPA, and the metals exceeding its ranges are shown in bold, together with MER values higher than $0.085 .{ }^{1}$ calculated as an estimation of mixing the two anolyte liquids, ${ }^{2}$ from the metal-depleted anolyte, *below LOD in ICP-OES.

\begin{tabular}{|c|c|c|c|c|c|c|c|c|c|c|c|c|c|}
\hline \multirow{2}{*}{ Parameter } & \multicolumn{11}{|c|}{ Experiment } & \multirow{2}{*}{$\begin{array}{c}\text { WPA } \\
\text { (Gilmour 2014) }\end{array}$} & \multirow{2}{*}{ Units } \\
\hline & $\mathrm{I} 1$ & $\mathrm{I} 2$ & $\mathrm{I}^{1}$ & $\mathrm{I} 4$ & I5 & G1 & G2 & G3 & $\mathrm{G}^{2}$ & G5 & G6 & & \\
\hline \% P-recovery & 66 & 66 & 68 & 73 & 80 & 63 & 69 & 68 & 64 & 40 & 39 & - & - \\
\hline Content of $\mathrm{P}$ & 4.6 & 3.7 & 2.3 & 4.2 & 6.2 & 4.1 & 5.2 & 5.5 & 4.4 & 3.5 & 3.2 & $\sim 340-450$ & g $P / L$ \\
\hline Content of S & 0.51 & 0.50 & 0.30 & 0.66 & 0.80 & 0.18 & 0.27 & 0.21 & 0.19 & 0.06 & 0.06 & $0.3-0.7$ & g S/L \\
\hline $\mathrm{Al} / \mathrm{P}$ & 0.16 & 0.17 & 0.06 & 0.14 & 0.12 & 0.10 & 0.10 & 0.09 & 0.06 & 0.13 & 0.21 & $<0.03$ & \\
\hline $\mathrm{Fe} / \mathrm{P}$ & 0.07 & 0.08 & 0.04 & 0.11 & 0.10 & 0.01 & 0.03 & 0.03 & $<0.01$ & 0.10 & 0.22 & $<0.04$ & $\mathrm{~kg} / \mathrm{kg} \mathrm{P}$ \\
\hline $\mathrm{Mg} / \mathrm{P}$ & 0.03 & 0.04 & 0.02 & 0.03 & 0.01 & 0.01 & 0.02 & 0.02 & $<0.01$ & 0.04 & 0.04 & $0.01-0.03$ & \\
\hline MER & 0.20 & 0.23 & 0.08 & 0.20 & 0.18 & 0.10 & 0.12 & 0.11 & 0.05 & 0.20 & 0.34 & - & - \\
\hline $\mathrm{As} / \mathrm{P}$ & 149 & 122 & 138 & 132 & 91 & 64 & 62 & 49 & 34 & 38 & 57 & $20-70$ & \\
\hline $\mathrm{Cd} / \mathrm{P}$ & 8 & 12 & 8 & 11 & 7 & 7 & $<4^{*}$ & $<4^{*}$ & $<5^{*}$ & $<6^{*}$ & $<6^{*}$ & $120-500$ & \\
\hline $\mathrm{Cr} / \mathrm{P}$ & 105 & 116 & 64 & 150 & 105 & 25 & 22 & 22 & 7 & 36 & 64 & $100-3,000$ & \\
\hline $\mathrm{Cu} / \mathrm{P}$ & 1,190 & 1,750 & 845 & 1,220 & 684 & 89 & 222 & 247 & 20 & 648 & 748 & $10-400$ & $\mathrm{mg} / \mathrm{kg} \mathrm{P}$ \\
\hline $\mathrm{Ni} / \mathrm{P}$ & 66 & 74 & 119 & 69 & 41 & 62 & 23 & 6 & 61 & 159 & 181 & $100-700$ & \\
\hline $\mathrm{Pb} / \mathrm{P}$ & 25 & 25 & 23 & 303 & 214 & $<5 *$ & $<4 *$ & 6 & 14 & $<6^{*}$ & 8 & $<4$ & \\
\hline $\mathrm{Zn} / \mathrm{P}$ & 917 & 1,200 & 628 & 977 & 963 & 203 & 279 & 249 & 35 & 472 & 782 & $100-10,000$ & \\
\hline
\end{tabular}




\section{CONCLUSIONS}

Two different ED methods were used in order to achieve comparable extraction of $\mathrm{P}$ from ashes of incineration and gasification of the same sewage sludge. For the former, a 2C setup allowed a recovery of up 80\%; for the latter a sequential ED process was required to recover up to $69 \%$ of $\mathrm{P}$, because of a higher presence of Fe(III)-P bindings and in order to prevent the formation of Fephosphate complexes. In general, higher remediation times allowed higher amount of recovered $\mathrm{P}$, although this was influenced by the inhomogeneity of the ashes. Using these techniques, the resulting $\mathrm{H}_{3} \mathrm{PO}_{4}$ solutions from gasification ash had overall lower ratios of $\mathrm{Al}, \mathrm{Fe}, \mathrm{Mg}$ and $\mathrm{HMs}$ to $\mathrm{P}$ than from incineration ash. This was possible due to lower solubilisation of most HMs in the gasification SSA, as well as the use of the additional step in the sequential ED process which involved P-extraction at high $\mathrm{pH}$, where most metals are insoluble.

The content of $\mathrm{Al}, \mathrm{Fe}, \mathrm{Mg}$ and some of the HMs was high in this liquids compared to WPA, which could complicate their usage in the production of commercial fertilizers like DAP. A considerable reduction of these impurities was obtained by using a new ED setup (split), making it an interesting alternative to separate P from SSA; especially because Fe concentration in commonly produced SSA tend to be higher than in the ashes of the present study.

\section{REFERENCES}

Ahrenfeldt, J., Thomsen, T., Henriksen, U. B., \& Clausen, L. R. 2013. Biomass gasification cogeneration - A review of state of the art technology and near future perspectives. Applied Thermal Engineering, 50(2), 1407-1417.

Cordell, D., \& White, S. 2014. Life's Bottleneck: Sustaining the World's Phosphorus for a Food Secure Future. In A. Gadgil \& D. M. Liverman, Annual Review of Environment and Resources, Vol 39, Palo Alto.

Donatello, S., Tong, D., \& Cheeseman, C. R. 2010. Production of technical grade phosphoric acid from incinerator sewage sludge ash (ISSA). Waste Management, 30(8-9), 1634-1642.

Ebbers, B., Ottosen, L. M., \& Jensen, P. E. 2015. Comparison of two different electrodialytic cells for separation of phosphorus and heavy metals from sewage sludge ash. Chemosphere, 125, 122129.

Franz, M. 2008. Phosphate fertilizer from sewage sludge ash (SSA). Waste Management, 28(10), 1809-1818.

Gil-Lalaguna, N., Sanchez, J. L., Murillo, M. B., \& Gea, G. 2015. Use of sewage sludge combustion ash and gasification ash for high-temperature desulphurization of different gas streams. Fuel, 141, 99-108.

Gilmour, R. 2014, Phosphoric Acid Purification, Uses, Technology, and Economics. CRC Press, Taylor\& Francis Group, Boca Raton, US.

Hansen, V., Müller-Stöver, D., Ahrenfeldt, J., Holm, J. K., Henriksen, U. B., \& Hauggaard-Nielsen, H. 2015. Gasification biochar as a valuable by-product for carbon sequestration and soil amendment. Biomass \& Bioenergy, 72, 300-308.

Hernandez, A. B., Ferrasse, J. H., Chaurand, P., Saveyn, H., Borschneck, D., \& Roche, N. 2011. Mineralogy and leachability of gasified sewage sludge solid residues. Journal of Hazardous Materials, 191(1-3), 219-227.

Krüger, O., \& Adam, C. 2015. Recovery potential of German sewage sludge ash. Waste Management, 45, 400-406.

Krüger, O., Grabner, A., \& Adam, C. 2014. Complete Survey of German Sewage Sludge Ash. Environmental Science \& Technology, 48(20), 11811-11818. 
Kuroda, K., \& Okido, M. 2012. Hydroxyapatite Coating of Titanium Implants Using Hydroprocessing and Evaluation of Their Osteoconductivity, Bioinorganic Chemistry and Applications, Volume 2012, pp. 730693.

Li, R. D., Zhang, Z. H., Li, Y. L., Teng, W. C., Wang, W. Y., \& Yang, T. H. 2015. Transformation of apatite phosphorus and non-apatite inorganic phosphorus during incineration of sewage sludge. Chemosphere, 141, 57-61.

Martinez, M. A., Gea, G., Arauzo, J., Kersten, S. R. A., \& Kootstra, A. M. J. 2014. Phosphorus recovery from sewage sludge char ash. Biomass \& Bioenergy, 65, 42-50.

Ottosen, L. M., Kirkelund, G. M., \& Jensen, P. E. 2013. Extracting phosphorous from incinerated sewage sludge ash rich in iron or aluminum. Chemosphere, 91(7), 963-969.

Ottosen, L. M., Jensen, P. E., \& Kirkelund, G. M. 2014. Electrodialytic Separation of Phosphorus and Heavy Metals from Two Types of Sewage Sludge Ash. Separation Science and Technology, 49(12), 1910-1920.

Parés Viader, R., Jensen, P. E., Ottosen, L. M., Ahrenfeldt, J., \& Hauggaard-Nielsen, H. (2015). Electrodialytic extraction of phosphorus from ash of low-temperature gasification of sewage sludge. Electrochimica Acta, 181, 100-108.

Parés Viader, R., Jensen, P. E., Ottosen, L. M., Ahrenfeldt, J., \& Hauggaard-Nielsen, H. (2016), Sequential electrodialytic recovery of phosphorus from low-temperature gasification ashes of chemically precipitated sewage sludge, Waste Management.

Samolada, M. C., \& Zabaniotou, A. A. 2014. Comparative assessment of municipal sewage sludge incineration, gasification and pyrolysis for a sustainable sludge-to-energy management in Greece. Waste Management, 34(2), 411-420.

Determination of metals in water, sludge and sediments - General guidelines for determination by atomic absorption spectrophotometry in flame. Danish Standard 259:2003, 2003.

Stumm, W., \& Morgan, J. J. 1996. Aquatic chemistry: Chemical equilibria and rates in natural waters. Wiley.

Scholz, R. W., Roy, A. H., Brand, F. S., Hellums, D. T., Ulrich, A. E. 2014, Sustainable phosphorus management : a global transdisciplinary roadmap. Springer, Heildeberg.

Mineral Commodity Summaries 2015, USGS, Virginia, USA.

van Dijk, K. C., Lesschen, J. P., \& Oenema, O. 2016. Phosphorus flows and balances of the European Union Member States. Science of the Total Environment, 542, 1078-1093. 